\title{
QUALITY OF LIFE OF PATIENT WITH MULTIPLE CEREBRAL ANEURYSMS AFTER ENDOVASCULAR TREATMENT: ASSESSMENT BY THE CRITERIA OF INTERNATIONAL CLASSIFICATION OF FUNCTIONING
}

Oleynik $A A^{1} \otimes$, Ivanova $\mathrm{NE}^{1}$, Oleynik $E A^{1}$, Ivanov $A \mathrm{Yu}^{2,3}$

${ }^{1}$ Almazov Medical Research Centre, St. Petersburg, Russia

${ }^{2}$ St. Petersburg State Pediatric Medical University, St. Petersburg, Russia

${ }^{3}$ North-Western State Medical University named after I. I. Mechnikov, St. Petersburg, Russia

The rate of mortality and disability associated with aneurysmal subarachnoid hemorrhage (SAH) is high. Patients with multiple cerebral aneurysms (MCA) require repeated surgeries more often and they are likely to develop aneurysms de novo and suffer their rupture. This study aimed to apply the International Classification of Functioning (ICF) to assess the quality of life (QOL) of MCA patients after endovascular treatment, late postoperative period. The study involved patients who underwent endovascular treatment and had multiple (>2) cerebral aneurysms (141 people). All patients underwent 1-6 endovascular surgeries; complications developed in 7.1\% (10/141) of cases. The patients' QOL was assessed against the ICF 6 to 24 months post-surgery. We found that at such time points treatment results deteriorate in a number of domains, namely those associated with pain, memory, motor coordination, limb strength. Patients with ruptured aneurysms showed worse results for locomotion-related domains than patients with unruptured aneurysms $(p<0.05)$, in patients with aneurysms having a pseudotumor type of flow, by domains associated with dysfunction of the cranial nerves responsible for innervation of the eye muscles $(p<0.001)(p<0.001)$. Patients with ruptured MCA were more active in the late post-surgery period, which was revealed by comparing that period's data to the baseline pre-surgery records $(p<0.05)$. The severity of activity disorders depended on surgery complications, patient age $(p<0.05)$, complications that developed during the acute SAH stage $(p<0.001)$.

Keywords: multiple cerebral aneurysms, quality of life, endovascular treatment, late aneurysms treatment results, optimization of medical rehabilitation

Author contribution: Oleynik AA — data collection, analysis and interpretation, literature analysis, article authoring; Ivanova NE — research planning, manuscript editing; Oleynik EA — literature analysis, statistical processing; Ivanov AYu — manuscript editing.

Compliance with ethical standards: the study was approved by the Ethics Committee of the Almazov National Medical Research Centre (minutes \#30 of February 13, 2017). All participants signed a voluntary consent to participate in the study.

$\square$ Correspondence should be addressed: Anna A. Oleynik

ul. Mayakovskogo, 12, St. Petersburg, 191014; doctor.an.an@mail.ru

Received: 19.11.2019 Accepted: 03.12.2019 Published online: 13.12.2019

DOI: $10.24075 /$ brsmu.2019.080

\section{ОЦЕНКА КАЧЕСТВА ЖИЗНИ ПО МЕЖДУНАРОДНОЙ КЛАССИФИКАЦИИ ФУНКЦИОНИРОВАНИЯ ПРИ МНОЖЕСТВЕННЫХ ЦЕРЕБРАЛЬНЫХ АНЕВРИЗМАХ ПОСЛЕ ЭНДОВАСКУЛЯРНОГО ЛЕЧЕНИЯ}

\author{
А. А. Олейник ${ }^{\boxplus}$, Н. Е. Иванова ${ }^{1}$, Е. А. Олейник ${ }^{1}$, А. Ю. Иванов 2,3 \\ ${ }^{1}$ Национальный медицинский исследовательский центр имени В. А. Алмазова, Санкт-Петербург, Россия \\ ${ }^{2}$ Санкт-Петербургский государственный педиатрический медицинский университет, Санкт-Петербург, Россия \\ ${ }^{3}$ Северо-Западный государственный медицинский университет имени И. И. Мечникова, Санкт-Петербург, Россия
}

Аневризматическое субарахноидальное кровоизлияние (САК) ассоциировано с высокой летальностью и инвалидизацией больных. Пациенты с множественными церебральными аневризмами (МА) чаще подвержены неоднократным оперативным вмешательствам, у них имеется вероятность образования аневризм de novo и их разрыва. Целью исследования было оценить качество жизни (КЖ) пациентов с помощью Международной классификации функционирования (МКФ) в отдаленном послеоперационном периоде после эндоваскулярного лечения МА для определения пути оптимизации реабилитации. В исследовании приняли участие оперированные эндоваскулярно пациенты с множественными (> 2) церебральными аневризмами (141 человек). Всем пациентам было выполнено 1-6 эндоваскулярных операций, осложнения лечения возникли в 7,1\% (10/141). КЖЖ определяли в сроки от 6 до 24 месяцев после операции, используя МКФ. Выявлено, что в отдаленном послеоперационном периоде результаты были хуже по доменам, связанным с болью, памятью, координацией движений, силой конечностей. При геморрагическом типе течения результаты по доменам, связанным с передвижением, были хуже по сравнению с другими типами течения ( $p<0,05)$, а при псевдоопухолевом - по доменам, связанным с нарушением функции черепно-мозговых нервов, отвечающих за иннервацию мышц глаза ( $p<0,001)$. По сравнению с показателями дооперационного периода в отдаленном послеоперационном периоде выявлено повышение активности и участия больных с геморрагическим типом течения ( $<<0,05)$. На выраженность нарушений активности влияли осложнения операций, возраст больных (p<0,05), осложнения острого периода САК (p < 0,001).

Ключевые слова: множественные церебральные аневризмы, качество жизни, эндоваскулярное лечение, отдаленные результаты лечения аневризм, оптимизация медицинской реабилитации

Информация о вкладе авторов: А. А. Олейник - сбор, анализ и интерпретация данных, анализ литературы, написание текста статьи; Н. Е. Иванова планирование исследования, редактирование рукописи; Е. А. Олейник - анализ литературы, статистическая обработка; А. Ю. Иванов — редактирование рукописи

Соблюдение этических стандартов: исследование одобрено этическим комитетом Национального медицинского исследовательского центра имени В. А. Алмазова (протокол № 30 от 13 февраля 2017 г.). Все участники подписали добровольное согласие на участие в исследовании.

$\bigotimes$ Для корреспонденции: Анна Анатольевна Олейник

ул. Маяковского, д. 12, г. Санкт-Петербург, 191014; doctor.an.an@mail.ru

Статья получена: 19.11.2019 Статья принята к печати: 03.12.2019 Опубликована онлайн: 13.12.2019

DOI: $10.24075 /$ vrgmu.2019.080

Cerebral aneurysms are some of the most common causes of subarachnoid hemorrhage (SAH) [1-2]. Over the past 30 years, the approaches to SAH treatment have changed significantly
[3]. Pathophysiological mechanisms of vasospasm and cerebral ischemia after SAH were investigated; understanding of these mechanisms allowed improving the acute period intensive care 
methods and reducing the incidence of ischemic complications [4-5]. The achievements in the field of cerebral aneurysm surgery, including methods designed specifically for the acute $\mathrm{SAH}$ period, the improvement of the methods of endovascular treatment of aneurysms resulted in reduction of the number of repeated SAH occurrences [6]. Advancements in non-invasive diagnostics and the growing availability of magnetic resonance angiography, computed tomography angiography enabled detection of asymptomatic cerebral aneurysms [7]. Assesing the risk of hemorrhage from an aneurysm takes into account the morphological features of the aneurysm (size, shape, location), the only treatment remains surgical intervention [8]. The rate of occurrence of complications related to such surgery ranges from 3 to 29\% [9-11]. However, to date the quality of life of patients after aneurysm surgery remains largely unresearched [12], regardless of such aneurysms staying asymptomatic or causing hemorrhage or have a pseudotumor course. It is known that up to $20-30 \%$ of patients acquire disabilities after intracranial hemorrhage [13]. The results of medical rehabilitation of SAH patients, as well as those suffering from post-surgery complications (ischemic or hemorrhagic), can be improved through optimization of rehabilitation algorithms by factoring in the principal neurological disorders [14]. Assessment of the quality of life of patients based on the International Classification of Functioning, Disability and Health (ICF) provides a holistic view of various aspects of their health [15]. This study aimed to apply the International Classification of Functioning (ICF) to assess the quality of life of MCA patients after endovascular treatment (late postoperative period); the goal was to discover the rehabilitation algorithms optimization paths.

\section{METHODS}

The study included MCA patients $(n=141)$ who received endovascular treatment at the Polenov Russian Research Institute of Neurosurgery in 2010-2018. Seventeen percent of the participants were male (24/141), $83 \%$ - female (117/141); the mean age of the patients was $54.16 \pm 11.24$ years. The inclusion criteria were: multiple $(>2)$ cerebral aneurysms treated endovascularly; opportunity to register late results. The exclusion criteria were: age below 18 years; concomitant arteriovenous malformations; history of microsurgical treatment of aneurysm. The number of aneurysms detected ranged from 2 to 6: 2 aneurysms in $62.4 \%$ of cases (88/141), 3 aneurysms in 26.2\% (36/141), 4 - in 7.8\% (11/141), 5 aneurysms in $2.8 \%(4 / 141), 6-$ in $0.7 \%(1 / 141)$. All in all, we detected 349 aneurysms in 141 cases. Their size varied: $22.9 \%(80 / 349)$ were miliary (up to $3 \mathrm{~mm}$ ) aneurysms, the size of $67.9 \%(237 / 349)$ was regular $(4-15 \mathrm{~mm}), 5.2 \%$ (18/349) were large $(16-25 \mathrm{~mm})$ and $4.0 \%(14 / 349)$ - gigantic (> 25mm). As for the clinical course pre-surgery, $45.4 \%$ (64 cases) of patients suffered one or several subarachnoid hemorrhages, $7.1 \%$ (10 cases) had a pseudotumor that affected surrounding structures volumetrically, and in $47.5 \%$ (67 cases) of patients the condition developed asymptomatically (accidentally detected aneurysms). All patients had 1 to 6 endovascular surgeries (271 surgeries in total): endovascular occlusion of aneurysms with detachable coils - 42.4\% (115/271), assisted (stent and balloon) endovascular occlusion of aneurysms with detachable coils - 32.8\% (89/271), flow diverter - 24.7\% (67/271). Complications after endovascular treatment (vasospasm, ischemic complications, hemorrhagic complications) occurred in $7.1 \%$ of cases (10/141), of which persistent neurological deficiency developed in $4.3 \%$ (6/141). We assessed the quality of life in the late period, 6 to 24 months postsurgery. For this purpose, we used the International Classification of Functioning, Disability and Health [15], focusing on the domains of body functions, activity and participation (Table 1).

All data were entered into a Microsoft Excel 7.0 spreadsheet. The clinical data obtained in the study were processed with STATISTICA for Windows 10.0 (StatSoft, Tulsa; USA). MannWhitney test, median $\chi^{2}$ and the ANOVA module were used to compare the quantitative parameters (scores by ICF domains, Rankin scale, Extended Glasgow Outcome Scale, Barthel Index of Activities of Daily Living (by age groups), SAH complications status, surgery-related complications status, pre-surgery disease development groups). Wilcoxon test was applied to evaluate the dynamics of the activity and participation domain indicators before and after surgery. The findings were considered statistically significant at $p<0.05$.

\section{RESULTS}

Figure 1 presents the assessment of neurological symptoms and patient complaints in the late postoperative period. Figure 2

Table 1. Domains of body functions, activity and participation, methods for their assessment

\begin{tabular}{|l|l|}
\hline \multicolumn{1}{|c|}{ Body functions domains } & \multicolumn{1}{|c|}{ Assessment method } \\
\hline b144 Memory functions & MMSE [16] \\
\hline b2152 Functions of external muscles of the eye & Isolated assessment of the eye muscle function using the Kurtzke Functional Systems Scores* \\
\hline b2702 Sensitivity to pressure & Scale score ${ }^{\star *}$ \\
\hline b167 Mental functions of language & Wasserman speech impairment scale [17] \\
\hline b28010 Pain in head and neck & Visual analogue scale for pain assessment [18] \\
\hline b320 Articulation functions & Severity assessment \\
\hline b730 Muscle power functions & Muscle power assessment scale \\
\hline b7602 Coordination of voluntary movements & GET UP AND GO TEST [19] \\
\hline d450 Walking & Six-minute walk test [20] \\
\hline d640 Doing housework & Rankin Scale [21], Extended Glasgow Outcome Scale [22] \\
\hline d510 Washing oneself & Barthel Index of Activities of Daily Living [23], Rankin Scale \\
\hline d540 Dressing & Barthel Index of Activities of Daily Living \\
\hline d550 Eating & Barthel Index of Activities of Daily Living \\
\hline
\end{tabular}

Note: * - 0 - no changes: 1 - symptoms present, no function impairment (mild disorder detected through neurological examination, no complaints from the patient) 2 - mild impairments (mild eye movement disorder, the patient complains of double vision, there is paresis of any one of the eye external muscles); 3 - moderate impairments (moderate eye movement disorder, the patient complains of double vision); 4 - severe impairments (paralysis of one or more of the eye external muscles); ${ }^{\star \star}$ — 0 — no impairments; 1 - mild impairments; 2 - moderate impairments; 3 — severe impairments; 4 — absolute impairments. 
presents the assessment of activity and participation domains by the "capacity" and "performance" qualifiers.

The ICF allows a systematic assessment of the state of body functions, with a single impairments severity scale; therefore, we established that the scores registered in the pain (b28010) and memory function (b144) domains were low more often than those describing the status in the voluntary movements coordination (b7602) and muscle power (b7302) domains. In the activity and participation section, the impairments were registered more often in the walking (d450) and housework (d640) domains.

Assessing the impairments detected in the late postsurgery period through the lens of pre-surgery aneurysm development pattern, we established that we found that in patients with ruptured aneurysms, the movement (b 7302, d4602, d640) domains indicators were significantly worse compared to the other types of multiple aneurysms development patterns $(p<0.05)$. Cranial nerves innervating the eye muscles (III, IV, VI) were significantly more often impaired in the group that had the aneurysms developing pseudotumors, even in the late postoperative period $(p<0.001)$. In other domains, we registered no significant difference between the MCA development patterns groups ( $p>0.05)$. Assessment of the cephalgic syndrome post-surgery revealed no significant difference in patients with ruptured and unruptured aneurysms. This fact underscores the importance of a detailed study of the cephalgic syndrome structure and its causes.

Comparing the pre-surgery data and those obtained in the late post-surgery period, we discovered that the patients with ruptured MCA enjoyed enjoyed a better quality of life in domains d4602 (Moving around outside the home and other buildings; Fig. 3) $(p=0.004)$ and d640 (Doing housework) $(p=0.03)$.

The severity of activity impairments (assessed with the Barthel Index of Activities of Daily Living, Rankin Scale, Extended Glasgow Outcome Scale) depended on post-surgery complications $(p<0.05)$, patient age from 51 to 60 years $(p<0.05)$, acute SAH period complications $(p<0.001)$.

The following complications were registered in the late postoperative period: aneurysm rupture $-1.4 \%$ (2/141, with focal neurological symptoms), vascular thrombosis $-2.1 \%$ (3/141, with focal neurological symptoms in one case). Due to the presence of an unoperated aneurysm that caused intracranial hemorrhage the patients were referred to surgery with subsequent rehabilitation measures.

Thus, using the ICF to score impairments allows qualifying the rehabilitation courses for such patients.

\section{DISCUSSION}

The results of our study confirm findings of other researchers [24-26]: a history of subarachnoid hemorrhages in patients with both single and multiple aneurysms negatively affect their functional status. Same as ours, a number of other reports describe the following factors that influence functional outcomes: age of patients at the time of hemorrhage [24], intraparenchymal hemorrhage [24-25], large and gigantic size of the aneurysm [25]. However, unlike other researchers, we did not register as such factors the medial cerebral artery localization of the aneurysm [24, 30] and intraventricular hemorrhage [27].

In the recent years, it became customary to apply the ICF to evaluate the results of treatment and/or rehabilitation in cases with disorders and injuries of the nervous system [28] and other body systems [29]. However, there is an insufficient number of studies addressing application of the ICF in the context of assessment of the results of endovascular treatment of MCA patients. The ICF was used to classify the determinants when summarizing data from various studies investigating QOL deterioration determinants in SAH survivors [30]. It was found that the determinants associated with body structure and

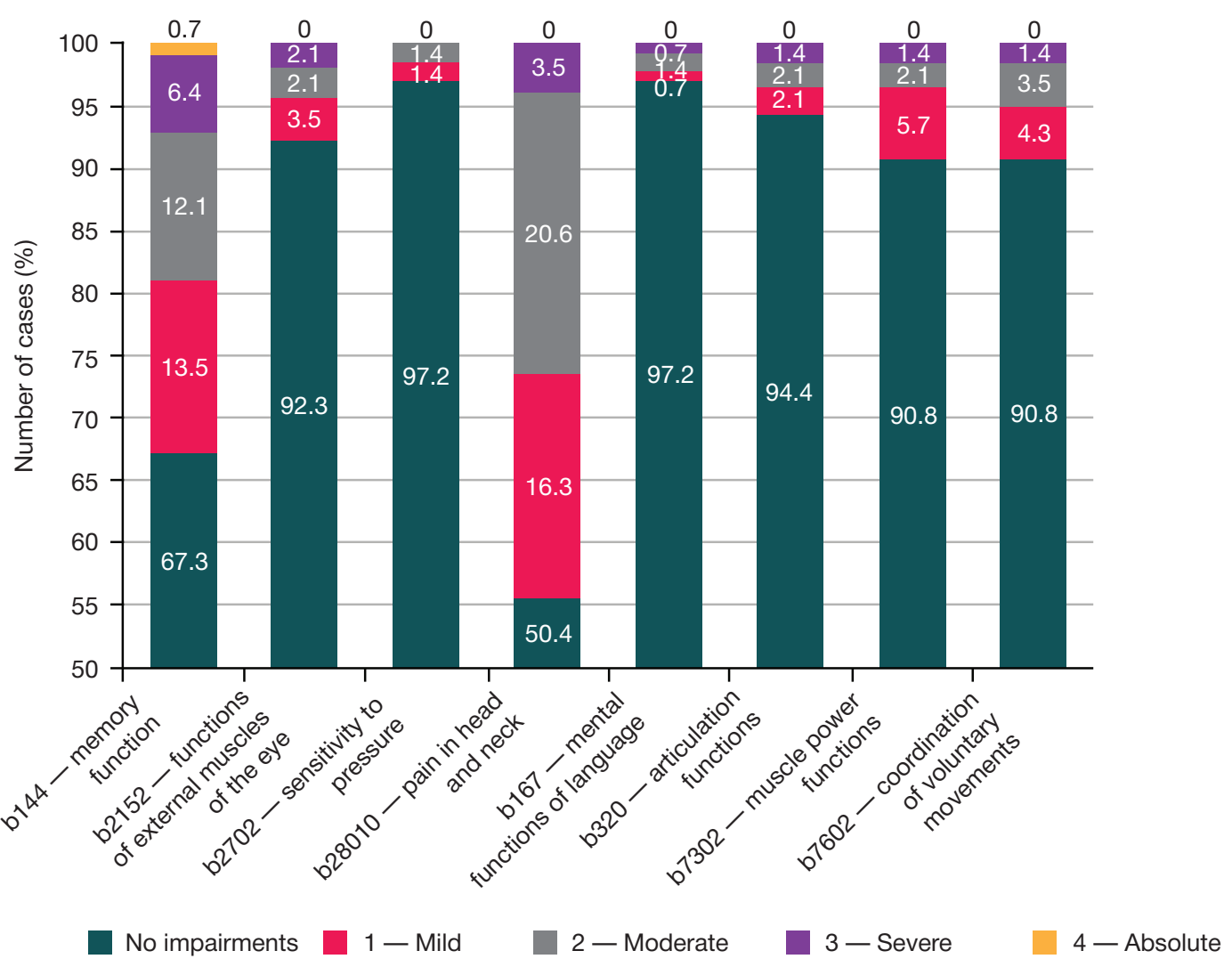

Fig. 1. Assessment by the body function domains, MCA patients, late postoperative period 


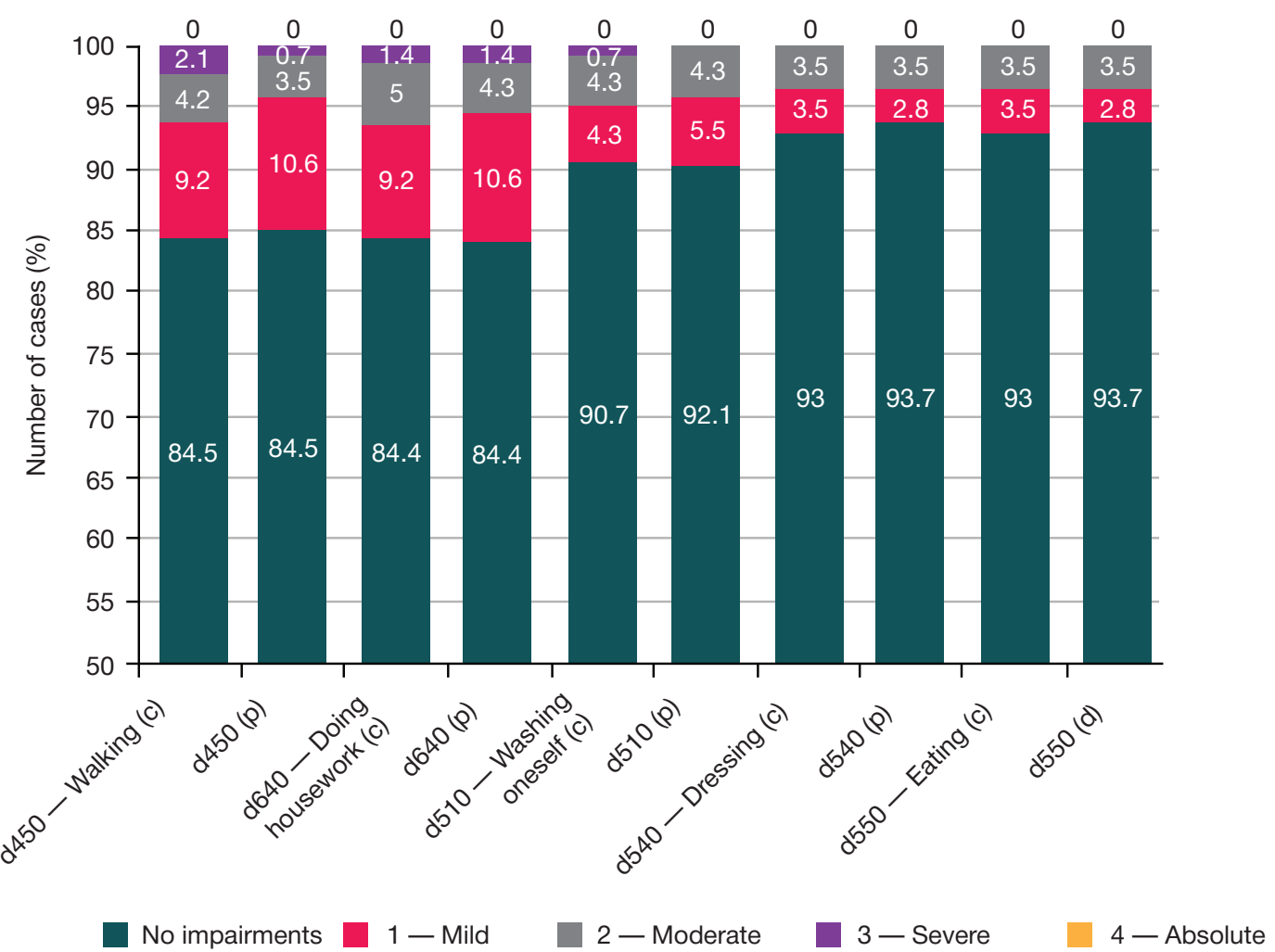

Fig. 2. Assessment by the activity and participation domains, "capacity" (c) and "performance" (p) qualifiers, MCA patients, late postoperative period

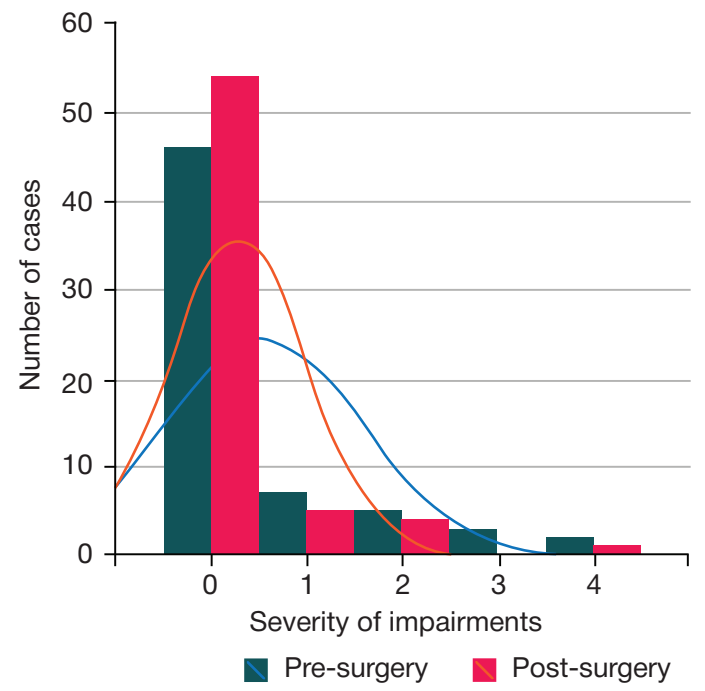

Fig. 3. Assessment by the d4602 domain (Moving around outside the home and other buildings), patients with hemorrhagic course MCA, pre-surgery and late post-surgery

functions (clinical condition at admission, low spirit), activity limitations (physical disability, cognitive status complaints) and personal factors (female sex, advanced age) negatively affect QOL post-SAH. Our study confirms that the QOL of patients with impaired body functions (b7302, b2152) deteriorates.

\section{CONCLUSIONS}

In the late postoperative period after endovascular treatment of MCA, a history of SAH and the presence of large aneurysms following the pseudotumor pattern are the factors that negatively affect the QOL of the patients. There is a risk of another SAH linked to the possibility of aneurysm formation de novo and aneurysm recanalization. Thus, further rehabilitation measures should account for neuroimaging data obtained in the late postoperative period. Application of the ICF to assess status of the patient's body functions, activity and participation, allow formulating the goals of rehabilitation, evaluating the results of endovascular treatment and further rehabilitation measures. Using separate scales disallows systematic analysis of the patient's condition. A single description of the severity of impairments is not only convenient in the context of evaluating the results, it also enables research efforts and comparison thereof. 
1. Krylov W, redaktor. Hirurgija anevrizm golovnogo mozga. V treh tomah. Tom I. M.: Izd-vo IP «T. A. Alekseeva», 2011; 432 s. Russian.

2. Azarov MV, Kupatadze DD, Nabokov VV. Sindrom KlippeljaTrenone, jetiologija, patogenez, diagnostika i lechenie. Pediatrija. 2018; 9 (2): 78-86. Russian.

3. La Pira B, Singh TD, Rabinstein AA, Lanzino G. Time Trends in Outcomes After Aneurysmal Subarachnoid Hemorrhage Over the Past 30 Years. Mayo Clin Proc. 2018 Dec; 93 (12): 1786-93.

4. Diringer MN, Zazulia AR. Aneurysmal Subarachnoid Hemorrhage: Strategies for Preventing Vasospasm in the Intensive Care Unit. Semin Respir Crit Care Med. 2017 Dec; 38 (6): 760-7.

5. Goroshhenko SA, Ivanova NE, Rozhchenko LV, Zabrodskaja YuM, Razmologova AYu, Kondratev AN, i dr. Jekstrapontinnyj mielinoliz, razvivshijsja posle anevrizmaticheskogo subarahnoidal'nogo krovoizlijanija (sluchaj iz praktiki i obzor literatury). Voprosy nejrohirurgii. 2016; (6): 82-7. Russian.

6. Anxionnat R, Tonnelet R, Derelle AL, Liao L, Barbier C, Bracard S. Endovascular treatment of ruptured intracranial aneurysms: Indications, techniques and results. Diagn Interv Imaging. 2015 Jul-Aug; 96 (7-8): 667-75.

7. Krylov W, Eliava ShSh, Yakovlev SB, Kheyreddin AS, Belousova OB, Polunina NA. Klinicheskie rekomendacii po lecheniju nerazorvavshihsja bessimptomnyh anevrizm golovnogo mozga. Voprosy nejrohirurgii. 2016; 80 (5): 124-35. Russian.

8. Wiebers DO, Whisnant JP, Huston J 3rd, Meissner I, Brown RD Jr, Piepgras DG, et al. International Study of Unruptured Intracranial Aneurysms Investigators. Unruptured intracranial aneurysms: natural history, clinical outcome, and risks of surgical and endovascular treatment. Lancet. 2003 Jul 12; 362 (9378): 103-10.

9. Ihn YK, Shin SH, Baik SK, Choi IS. Complications of endovascular treatment for intracranial aneurysms: Management and prevention. Interv Neuroradiol. 2018 Jun; 24 (3): 237-45.

10. Oishi H, Yamamoto M, Shimizu T, Yoshida K, Arai H. Endovascular therapy of 500 small asymptomatic unruptured intracranial aneurysms. AJNR Am J Neuroradiol. 2012 May; 33 (5): 958-64

11. Kim DY, Park JC, Kim JK, Sung YS, Park ES, Kwak JH, Choi CG, Lee DH. Microembolism after Endovascular Treatment of Unruptured Cerebral Aneurysms: Reduction of its Incidence by Microcatheter Lumen Aspiration. Neurointervention. 2015 Sep; 10 (2): 67-73.

12. Dammann $P$, Wittek $P$, Darkwah Oppong $M$, Hütter $B O$, Jabbarli $R$, et al. Relative health-related quality of life after treatment of unruptured intracranial aneurysms: long-term outcomes and influencing factors. Ther adv neurol disord. 2019; (12): 1-12.

13. le Roux AA, Wallace MC. Outcome and cost of aneurysmal subarachnoid hemorrhage. Neurosurg Clin N Am. 2010 Apr; 21 (2): 235-46.

14. Geyh S, Cieza A, Schouten J, Dickson H, Frommelt P, Omar Z, et al. ICF Core Sets for stroke. J Rehabil Med. 2004 Jul; (44 Suppl): 135-41.

15. World Health Organization. International Classification of Functioning, Disability and Health: ICF. Geneva: WHO; 2001.

16. Folstein MF, Folstein SE, McHugh PR. «Mini-mental state» a practical method for grading the cognitive state of patients for the clinician. Journal of Psychiatric Research. 1975; 12 (3): 189-98.

17. Vasserman LI, Dorofeeva SA, Meerson YaA. Metody nejropsihologicheskoj diagnostiki. Prakticheskoe rukovodstvo. SPb.: Strojlespechat', 1997. Russian.

18. Scott J, Huskisson EC. Graphic representation of pain. Pain. 1976; 2 (2): 175-84.

19. Mathias S, Nayak US, Isaacs B. Balance in elderly patients: the "get-up and go" test. Arch Phys Med Rehabil. 1986 Jun; 67 (6): 387-9.

20. American Thoracic Society statement: guidelines for the sixminute walk test. Am J Respir Crit Care Med. 2002; 166 (1) $111-7$

21. Bonita R, Beaglehole R. Modification of Rankin Scale: Recovery of motor function after stroke. Stroke. 1988 Dec; 19 (12): 1497-500.

22. Wilson JT, Pettigrew LE, Teasdale GM. Structured interviews for the Glasgow Outcome Scale and the extended Glasgow Outcome Scale: guidelines for their use. J Neurotrauma. 1998; (15): 573-85

23. Mahoney F, Barthel D. Functional evaluation: the Barthel Index. Md Med J. 1965; (14): 61-5.

24. Preiss M, Netuka D, Koblihova J, Bernardova L, Charvat F Kratochvilova D, et al. Quality of life 1 year after aneurysmal subarachnoid hemorrhage in good outcome patients treated by clipping or coiling. J Neurol Surg A Cent Eur Neurosurg. 2012 Aug; 73 (4): 217-23.

25. Andersen CR, Fitzgerald E, Delaney A, Finfer S. Systematic Review of Outcome Measures Employed in Aneurysma Subarachnoid Hemorrhage (aSAH). Clin res neurocritical care. 2019; 30 (3): 534-41.

26. AlMatter $M$, Aguilar Péreza $M$, Bhogal $P$, Hellstern V, Ganslandt $O$ Henkes $H$. Results of interdisciplinary management of 693 patients with aneurysmal subarachnoid hemorrhage: Clinical outcome and relevant prognostic factors. Clin Neurol Neurosurg. 2018 Apr; (167): 106-11.

27. Visser-Meily JMA, Rhebergen ML, Rinkel GJE, van Zandvoort MJ, Post MWM. Long-term health related quality of life after aneurysmal subarachnoid hemorrhage; relationship with psychological symptoms and personality characteristics. Stroke. 2009; (40): 1526-9.

28. Bodrova RA, Auhadeev Yel, Tihonov IV. Opyt primenenija mezhdunarodnoj klassifikacii funkcionirovanija $v$ ocenke jeffektivnosti reabilitacii pacientov s posledstvijami porazhenija CNS. Prakticheskaja medicina. 2013; 1 (66): 98-100. Russian.

29. Ponomarenko GN, Shoshmin AV, Besstrashnova YaK, Cherkashina IV. Planirovanie i ocenka jeffektivnosti reabilitacii bol'nyh osteoartrozom: ispol'zovanie bazovogo nabora Mezhdunarodnoj klassifikacii funkcionirovanija, ogranichenij zhiznedejatel'nosti i zdorov'ja. Voprosy kurortologii, fizioterapii lechebnoj fizicheskoj kul'tury. 2017; (1): 4-8. Russian.

30. Passier PE, Visser-Meily JM, Rinkel GJ, Lindeman E, Post MW. Determinants of health-related quality of life after aneurysmal subarachnoid hemorrhage: a systematic review. Qual Life Res. 2013 Jun; 22 (5): 1027-43.

\section{Литература}

1. Крылов В. В., редактор. Хирургия аневризм головного мозга. В трех томах. Том І. М.: Изд-во ИП «Т. А. Алексеева», 2011; 432 c.

2. Азаров М. В., Купатадзе Д. Д., Набоков В. В. Синдром Клиппеля-Треноне, этиология, патогенез, диагностика и лечение. Педиатрия. 2018; 9 (2): 78-86.

3. La Pira B, Singh TD, Rabinstein AA, Lanzino G. Time Trends in Outcomes After Aneurysmal Subarachnoid Hemorrhage Over the Past 30 Years. Mayo Clin Proc. 2018 Dec; 93 (12): 1786-93.

4. Diringer MN, Zazulia AR. Aneurysmal Subarachnoid Hemorrhage: Strategies for Preventing Vasospasm in the Intensive Care Unit. Semin Respir Crit Care Med. 2017 Dec; 38 (6): 760-7.

5. Горощенко С. А., Иванова Н. Е., Рожченко Л. В., Забродская Ю. М., Размологова А. Ю., Кондратьев А. Н. и др. Экстрапонтинный миелинолиз, развившийся после аневризматического субарахноидального кровоизлияния (случай из практики и обзор литературы). Вопросы нейрохирургии. 2016; (6): 82-7.

6. Anxionnat R, Tonnelet R, Derelle AL, Liao L, Barbier C, Bracard S. Endovascular treatment of ruptured intracranial aneurysms: Indications, techniques and results. Diagn Interv Imaging. 2015 Jul-Aug; 96 (7-8): 667-75.

7. Крылов В. В., Элиава Ш. Ш., Яковлев С. Б., Хейреддин А. С., Белоусова О. Б., Полунина Н. А. Клинические рекомендации 
по лечению неразорвавшихся бессимптомных аневризм головного мозга. Вопросы нейрохирургии. 2016; 80 (5): 124-35.

8. Wiebers DO, Whisnant JP, Huston J 3rd, Meissner I, Brown RD Jr, Piepgras DG, et al. International Study of Unruptured Intracranial Aneurysms Investigators. Unruptured intracranial aneurysms: natural history, clinical outcome, and risks of surgical and endovascular treatment. Lancet. 2003 Jul 12; 362 (9378): 103-10.

9. Ihn YK, Shin SH, Baik SK, Choi IS. Complications of endovascular treatment for intracranial aneurysms: Management and prevention. Interv Neuroradiol. 2018 Jun; 24 (3): 237-45.

10. Oishi H, Yamamoto M, Shimizu T, Yoshida K, Arai H. Endovascular therapy of 500 small asymptomatic unruptured intracranial aneurysms. AJNR Am J Neuroradiol. 2012 May; 33 (5): 958-64.

11. Kim DY, Park JC, Kim JK, Sung YS, Park ES, Kwak JH, Choi CG, Lee DH. Microembolism after Endovascular Treatment of Unruptured Cerebral Aneurysms: Reduction of its Incidence by Microcatheter Lumen Aspiration. Neurointervention. 2015 Sep; 10 (2): $67-73$.

12. Dammann $P$, Wittek $P$, Darkwah Oppong $M$, Hütter $B O$, Jabbarli $R$, et al. Relative health-related quality of life after treatment of unruptured intracranial aneurysms: long-term outcomes and influencing factors. Ther adv neurol disord. 2019; (12): 1-12.

13. le Roux AA, Wallace MC. Outcome and cost of aneurysmal subarachnoid hemorrhage. Neurosurg Clin N Am. 2010 Apr; 21 (2): 235-46.

14. Geyh S, Cieza A, Schouten J, Dickson H, Frommelt P, Omar Z, et al. ICF Core Sets for stroke. J Rehabil Med. 2004 Jul; (44 Suppl): 135-41.

15. World Health Organization. International Classification of Functioning, Disability and Health: ICF. Geneva: WHO; 2001.

16. Folstein MF, Folstein SE, McHugh PR. "Mini-mental state» a practical method for grading the cognitive state of patients for the clinician. Journal of Psychiatric Research. 1975; 12 (3): 189-98.

17. Вассерман Л. И., Дорофееева С. А., Меерсон Я. А. Методь нейропсихологической диагностики. Практическое руководство. СПб.: Стройлеспечать, 1997.

18. Scott J, Huskisson EC. Graphic representation of pain. Pain. 1976; 2 (2): 175-84

19. Mathias S, Nayak US, Isaacs B. Balance in elderly patients: the "get-up and go" test. Arch Phys Med Rehabil. 1986 Jun; 67 (6): 387-9.

20. American Thoracic Society statement: guidelines for the sixminute walk test. Am J Respir Crit Care Med. 2002; 166 (1):
111-7.

21. Bonita R, Beaglehole R. Modification of Rankin Scale: Recovery of motor function after stroke. Stroke. 1988 Dec; 19 (12): 1497-500.

22. Wilson JT, Pettigrew LE, Teasdale GM. Structured interviews for the Glasgow Outcome Scale and the extended Glasgow Outcome Scale: guidelines for their use. J Neurotrauma. 1998; (15): 573-85

23. Mahoney F. Barthel D. Functional evaluation: the Barthel Index. Md Med J. 1965; (14): 61-5

24. Preiss M, Netuka D, Koblihova J, Bernardova L, Charvat F, Kratochvilova D, et al. Quality of life 1 year after aneurysmal subarachnoid hemorrhage in good outcome patients treated by clipping or coiling. J Neurol Surg A Cent Eur Neurosurg. 2012 Aug; 73 (4): 217-23.

25. Andersen CR, Fitzgerald E, Delaney A, Finfer S. Systematic Review of Outcome Measures Employed in Aneurysmal Subarachnoid Hemorrhage (aSAH). Clin res neurocritical care. 2019; 30 (3): 534-41.

26. AlMatter $M$, Aguilar Péreza $M$, Bhogal $P$, Hellstern V, Ganslandt $O$, Henkes H. Results of interdisciplinary management of 693 patients with aneurysmal subarachnoid hemorrhage: Clinical outcome and relevant prognostic factors. Clin Neurol Neurosurg. 2018 Apr; (167): 106-11.

27. Visser-Meily JMA, Rhebergen ML, Rinkel GJE, van Zandvoort MJ, Post MWM. Long-term health related quality of life after aneurysmal subarachnoid hemorrhage; relationship with psychological symptoms and personality characteristics. Stroke. 2009; (40): 1526-9.

28. Бодрова Р. А., Аухадеев Э. И., Тихонов И. В. Опыт применения международной классификации функционирования в оценке эсфективности реабилитации пациентов с последствиями поражения ЦНС. Практическая медицина. 2013; 1 (66): 98-100.

29. Пономаренко Г. Н., Шошмин А. В., Бесстрашнова Я. К., Черкашина И. В. Планирование и оценка эффективности реабилитации больных остеоартрозом: использование базового набора Международной классификации функционирования, ограничений жизнедеятельности и здоровья. Вопросы курортологии, физиотерапии и лечебной физической культуры. 2017; (1): 4-8.

30. Passier PE, Visser-Meily JM, Rinkel GJ, Lindeman E, Post MW. Determinants of health-related quality of life after aneurysmal subarachnoid hemorrhage: a systematic review. Qual Life Res. 2013 Jun; 22 (5): 1027-43. 